\title{
Technology on mixed forage nutrition collocation and development of grass-based stockbreeding in the karst rocky desertification area
}

\author{
Yu Zhang ${ }^{1, a}$, Kangning Xiong ${ }^{1, b} *$, Xiaoyun Shen ${ }^{2, c}$ \\ ${ }^{1}$ School of Karst Science, Guizhou Normal University / State Engineering Technology Institute for \\ Karst Desertification Control, Guiyang 550001, P.R.China
}

2 State Engineering Technology Institute for Karst Desertification Control, Guiyang 550001, P.R.China

axiongkn@163.com, ${ }^{\mathrm{b}}$ hxcandzy@163.com, 'bijishenxy@163.com

\begin{abstract}
Key words: mixed forage; configuration proportion; stockbreeding; karst rocky desertification Abstract In order to study forage mixture skills and solve livestock's nutrient deficiency for the adaptive development of grassland stockbreeding in the karst rocky desertification areas, this paper chose the alfalfa (Medicago sativa) and rescuegrass (Bromus catharticus) which grow well in the karst areas for the nutrition degradability measurements of six castrative Guizhou white goats installed perpetual rumen fistula by Nylon Bag Technique. Test group is $100 \%$ rescuegrass (Control group I), 10\% alfalfa and 90\% rescuegrass (Experiment group I), 30\% alfalfa and $70 \%$ rescuegrass (Experiment group II), 50\% alfalfa and 50\% rescuegrass (Experiment group III), 70\% alfalfa and $30 \%$ rescuegrass (Experiment group IV), 90\% alfalfa and 10\% rescuegrass (Experiment group V) and $100 \%$ alfalfa (Control group II). The results indicate that the degradation rate to dry matter (DM) of the mixed forage is bigger than that of single forage; the degradation rate of crude protein (CP) is increasing with percentage of legume; there is no obvious variation tendency of the degradability of neutral detergent fiber (NDF) and acid detergent fiber (ADF). However, the degradation rate in experiment group II is the biggest. The comprehensive analysis for digestion and utilization situations of the white goats with the forages above shows that the nutrition conversion of the mixed forage is bigger than that of the single forage; the best mixture percentage between legume and grasses forage is 3:7. As a result, we suggest this configuration proportion in the grass land construction and the grassland stockbreeding development of the national rocky desertification control.
\end{abstract}

\section{Introduction}

Guizhou is considered as typical karst fragile environment with complex human-land eco-system in the world. Because of human beings' unreasonable actions, there exist such phenomena in the karst areas as follows: rock bareness, soil depletion; fragile environment; extensive rocky desertification, which have been the most serious eco-environment problems ${ }^{[1]}$. How to break this vicious cycle of "poverty-seize resource -gradual environmental degradation and deterioration-further poverty" is the primary task to restore the rocky desertification ecological environment ${ }^{[2]}$. Academician Yuan ${ }^{[3]}$ pointed out that the pattern of grassland stockbreeding development was a systematic engineering of rocky desertification control, and the control of rocky desertification could not get rid of the development of herbivorous animal husbandry ${ }^{[4]}$. And, karst rocky desertification region in southern China could provide superior natural geography conditions for developing grassland stockbreeding. Meanwhile, promoting the development of grassland stockbreeding is an effective method to solve the problem of rural poverty and to improve the ecological environment in karst areas. How to make full use of forage resources to improve the forage utilization efficiency for development of grassland stockbreeding is the main task of the national rocky desertification control project in the Planning Outline of Karst Rocky Desertification Comprehensive Control (2006-2015) approved by the State Council in 2008.

There are more mountains than hills in karst rocky desertification areas of southwest China, with broken and complex terrain, steep slope shrub and rich scrub-grassland resources. Compared with sheep, goats have a strong climbing and jumping ability and are good at climbing, making them active in the mountains. Simultaneously, the omnivorous goats, easy to raise, fast-breeding animal, 
with good meat and pelt quality, little muttony odour, are highly favored by the local market ${ }^{[5,6]}$. But the feeding of goats has some destructive effects on the ecological environment, so it is essential to develop fence livestock and combine grazing with stall-feeding. In order to meet the nutritional needs of stall-feeding in karst areas, the main problem we are facing is to choose drought-tolerant forage to nutrition arrange nutrition in extremely arid conditions. Medicago sativa L., known as "king of forage" and "feed queen", is a kind of firstly used and the most widely cultivated legume forages with high nutritional value and good palatability, so it can be described as an important representative of legumes ${ }^{[7,8,9]}$. Bromus cartharticus Vahl., a species of perennial gramineous forage grasses, has the characteristics of cold resistance, drought tolerance, acid and alkali resistant, fast growth rate, high tillering ability, strong stress resistance, high yields, good regenerability, long grass supply period, and so on ${ }^{[10]}$. Mingkun Zhao ${ }^{[11]}$ researches on planting forage in Guizhou karst areas indicate that Bromus cartharticus Vahl., Festuca arundinacea, Dactylis glomerata L., and other indicators have good characters after comprehensive analysis and can be widely cultivated in development and utilization in future. Bromus cartharticus Vahl. has a wide planting area in karst rocky desertification areas at present. Based on the previous researches, the mixture sowing of legume and grasses could not only improve nitrogen nutrition balance in grass eco-system, promote the formation of grass animal protein ${ }^{[12,13]}$, improve the quality and quantity of grass ${ }^{[14]}$, but also increase soil fertility. Xie ${ }^{[15]}$ and others also mentioned that the planting technology of mixture sowing of grass could promote the output of forage and meet the needs of flocks and herds. However, the researches on using the matching technology of mixed forage nutrition collocation to develop grassland stockbreeding are quite new at present. Determining the proportion of composition and collocation of mixture sowing is an extremely complex issue, and the choice is reasonable or not can affect the potential of the mixture sowing directly [ ${ }^{16]}$. Therefore, this research focused on Guizhou white goats, and chose representative and superior legume alfalfa and grasses rescuegrass, adopted nylon bag technique, evaluated the nutritive value of forage by measuring the in-vivo digestive rate of the white goats to forage, and suggested a superior matching technological scheme for the mixed forage to promote the adaptive development of grassland construction and grass-based stockbreeding in the national rocky desertification control project.

\section{Materials and methods}

\section{Collection and process of forage grass samples}

Four species of forage were planted in the scientific demonstration plot for the rocky desertification integrated control and the mixed agriculture and forestry of karst plateau-mountains in Salaxi Bijie in March 2013. The soil physical and chemical properties in Karst demonstration zone are listed in (Table 1). Alfalfa and rescuegrass were clipped with a stubble height of 4 centimeters in October 2014. They were killed out in the oven at the temperature of $105^{\circ} \mathrm{C}$ for 15 minutes and then oven-dried to a constant weight at the temperature of $65^{\circ} \mathrm{C}$. The oven-dried plant materials were smashed, sieved and sealed.

Table 1 Physical and chemical properties of soil in karst demonstration area

\begin{tabular}{|c|c|c|c|}
\hline Physical properties of soil & Content & Chemical properties of soil & $\begin{array}{l}\text { Conte } \\
\mathrm{nt}\end{array}$ \\
\hline Moisture capacity (\%) & 16.87 & $\mathrm{PH}$ value & 6.55 \\
\hline Bulk density $\left(\mathrm{g} / \mathrm{cm}^{3}\right)$ & 1.1 & Organic matter content $(\mathrm{mg} / \mathrm{kg})$ & 47.52 \\
\hline Field moisture capacity (\%) & 35.6 & Total nitrogen content $(\mathrm{g} / \mathrm{kg})$ & 2.46 \\
\hline Capillary moisture capacity (\%) & 45.16 & Total phosphorus content $(\mathrm{g} / \mathrm{kg})$ & 2.44 \\
\hline Total porosity $(\%)$ & 69.12 & Total potassium content $(\mathrm{g} / \mathrm{kg})$ & 5.81 \\
\hline Capillary porosity $(\%)$ & 69.12 & Hydrolysis nitrogen content & 112.66 \\
\hline Non-capillary porosity $(\%)$ & 27.31 & $(\mathrm{mg} / \mathrm{kg})$ & 5.65 \\
\hline $\begin{array}{l}\text { Upper strata saturated permeability } \\
(\mathrm{mm} / \mathrm{mm})\end{array}$ & $\begin{array}{l}17.74 \\
12.66\end{array}$ & $\begin{array}{l}\text { Available phosphorus content } \\
(\mathrm{mg} / \mathrm{kg})\end{array}$ & 95.87 \\
\hline $\begin{array}{l}\text { Lower strata saturated permeability } \\
(\mathrm{mm} / \mathrm{mm})\end{array}$ & & $\begin{array}{l}\text { Available potassium } \\
(\mathrm{mg} / \mathrm{kg})\end{array}$ & \\
\hline
\end{tabular}




\section{Experimental animals and diet composition}

This experiment totally chose six castrated Guizhou white goats with the average weight $39.18 \pm 1.45 \mathrm{~kg}$, operated perpetual rumen fistula according to the operation method of Lu Dexun et a.l ${ }^{[17]}$, and evaluated the changing situations of degradation rate of the mixed forage nutrient substance by Nylon Bag Technique with different proportion of alfalfa and rescuegrass in rumen for $4 \mathrm{~h}, 8 \mathrm{~h}, 16 \mathrm{~h}, 24 \mathrm{~h}, 48 \mathrm{~h}$ and $72 \mathrm{~h}$. The forage-to-concentrate ratio of the Guizhou white goats was 3:7, and basic ration composition and nutritional level were shown in (Table 2).

Table 2 Diet composition and nutritional level (air drying)

\begin{tabular}{lc|lc}
\hline Diet composition & $\begin{array}{c}\text { Content, } \\
\%\end{array}$ & Nutrient level & Content, $\%$ \\
\hline Corn straw & 60 & CP & 14.51 \\
Corn & 23 & NDF & 55.36 \\
Rapeseed meal & 12 & ADF & 36.01 \\
Salt & 0.5 & EE & 1.35 \\
Urea & 2 & Ca & 0.96 \\
Mineral & 1.5 & P & 0.6 \\
Premix & 1 & Ash & 7.95 \\
Totol & 100 & & \\
\hline
\end{tabular}

\section{Feeding and management}

Cleaning, disinfecting, expelling parasite and other related prevention work of sheep cots are in the preliminary trial period before the experiments for 15 days. During the experiment, the white goats were fed with nutritional materials under the level of 1.4 times that required. The daily feeding time was 8:00 a.m. and 6:00 p.m. and white goats could drink water freely.

\section{Experimental methods}

Experiment is divided into test group is $100 \%$ rescuegrass (Control group I), $10 \%$ alfalfa and $90 \%$ rescuegrass (Experiment group I), 30\% alfalfa and 70\% rescuegrass (Experiment group II), 50\% alfalfa and 50\% rescuegrass (Experiment group III), 70\% alfalfa and 30\% rescuegrass (Experiment group IV), $90 \%$ alfalfa and 10\% rescuegrass (Experiment group V) and 100\% alfalfa (Control group II).

The Nylon Bag Technique ${ }^{[18]}$ was adopted to measure in this experiment. Nylon cloth with apertures of 400 meshes was cut into sample sacks of $12 \mathrm{~cm}$ length and $6 \mathrm{~cm}$ width. In each sample sack, there were about $3.5 \mathrm{~g}$ samples. Every three sacks were tied together and regarded as one group. The sample sacks were let sit and sampled at $4 \mathrm{~h}, 8 \mathrm{~h}, 16 \mathrm{~h}, 24 \mathrm{~h}, 48 \mathrm{~h}$ and $72 \mathrm{~h}$, respectively. The samples of $0 \mathrm{~h}$ was a mixture of paralleling subsamples in nylon bags, and was steeped for 1 hour with $37^{\circ} \mathrm{C}$ water bath. All samples were washed with tap water slowly until the washed water was clear. And then, the nylon bags were oven-dried to a constant weight at $65^{\circ} \mathrm{C}$ for about 48 hours. The measurement method of Dry matter (DM) was to use an oven to dry to constant weight, the crude protein (CP) was measured by Kjeldahl Nitrogen Determination Method (GB/T6432-94), and neutral detergent fiber (NDF) and acid detergent fiber (ADF) by Fiber Bag Method.

\section{Calculation method of fodder degradation rate}

The degradation rates of DM, CP, NDF and ADF were calculated as a balance of the nutrient composition of the forage grass before and after degradation as below:

Degradation Rate $(\%)=\{$ (Concentration before degradation-Concentration after degradation $) /$ Concentration before degradation $\} \times 100 \%$

The dynamic degradation rate of sample was calculated in accordance with formula proposed by prskov et al ${ }^{[19]}$.

$$
p=a+b\left(1-e^{-c t}\right)
$$


Where $p$ and $t$ are the degradation rate of $t$ time, time of fodder stay in rumen, respectively; $a, b$ and $\mathrm{c}$ are rapidly degradable fraction, slowly degradable fraction, degradation constant of $b$, respectively.

The effective degradation rate was calculated as following.

$$
E D=a+b[c /(c+k)]
$$

(2)

Where ED and $\mathrm{K}$ are effective degradation in test fodder, efflux speed of chyme in rumen $(\% / \mathrm{h})$, forage $0.02 / \mathrm{h}^{[20]}$, respectively. a, b, c ditto.

\section{Statistic analysis}

ANOVA was performed to test the significance using SPSS version 13.0 software package. A level of 0.05 was used as a standard of significance. Repeated measures ANOVA in a generalized linear model were used to examine the differences of parameter.

\section{Results}

\section{Digest regularity of white goats to forage DM}

The degradation rate of DM was increasing with the degradation time of forage, and the degradation rates of both the group IV and the control group II in different periods showed a great difference $(P<0.05)$. The degradation rates of the mixed forage at 48 and $72 \mathrm{~h}$ in the experiment group showed an incremental but not significant tendency with the increasing replacing proportion of alfalfa. The DM degradation rate of the white goats' to mixed forage at $48 \mathrm{~h}$ and $72 \mathrm{~h}$ was higher than that of the control group to single forage. The degradation rate of DM was the group $\mathrm{V}>$ the group IV $>$ the group III $>$ the group II $>$ the group I $>$ the control group II $>$ the control group I (Table 3 ).

Table 3 Dynamic degradation rate of the forage DM in Guizhou white goats' rumen

\begin{tabular}{|c|c|c|c|c|c|c|}
\hline \multirow{2}{*}{ Item } & \multicolumn{6}{|c|}{ Degradation time $(\mathrm{h})$} \\
\hline & 4 & 8 & 16 & 24 & 48 & 72 \\
\hline $\begin{array}{l}\text { Control } \\
\text { group I }\end{array}$ & $\underset{\mathrm{aD}}{20.66 \pm 1.53}$ & $\begin{array}{c}24.07 \pm 3.80^{\text {eff }} \\
\text { D }\end{array}$ & $\begin{array}{c}30.37 \pm 8.08^{c} \\
\text { BC }\end{array}$ & $36.7 \pm 10.68^{\mathrm{dB}}$ & $\underset{\mathrm{eA}}{45.52 \pm 4.42 \mathrm{~b}^{\mathrm{cd}}}$ & $46.52 \pm 4.42^{\mathrm{eA}}$ \\
\hline $\begin{array}{l}\text { Experiment } \\
\text { group I }\end{array}$ & $\underset{b \mathrm{bD}}{16.14 \pm 0.01}$ & $\begin{array}{c}19.99 \pm 0.02^{\mathrm{f}} \\
\mathrm{D}\end{array}$ & $\underset{C}{29.87 \pm 0.02^{c}}$ & $\underset{\mathrm{dB}}{40.97 \pm 0.02^{\mathrm{bc}}}$ & $51.9 \pm 0.03^{\mathrm{adA}}$ & $\underset{A}{56.19 \pm 0.10^{\mathrm{ad}}}$ \\
\hline $\begin{array}{l}\text { Experiment } \\
\text { group II }\end{array}$ & $\underset{\mathrm{bD}}{18.23 \pm 0.03}$ & $\underset{\mathrm{cC}}{32.36 \pm 0.04^{\mathrm{b}}}$ & $\underset{\mathrm{B}}{45.40 \pm 0.12^{\mathrm{a}}}$ & $\underset{\mathrm{B}}{48.59 \pm 0.07^{\mathrm{ab}}}$ & $51.31 \pm 0.02^{\mathrm{aeB}}$ & $\underset{\mathrm{A}}{60.32 \pm 0.01^{\mathrm{ac}}}$ \\
\hline $\begin{array}{l}\text { Experiment } \\
\text { group III }\end{array}$ & $\underset{B}{11.94 \pm 0.02^{c}}$ & $\underset{f B}{23.99} \pm 0.03^{\mathrm{d}}$ & $33.7 \pm 0.02^{\mathrm{cB}}$ & $41.12 \pm 0.02^{b \mathrm{c}}$ & $53.96 \pm 0.03^{\mathrm{acB}}$ & $\underset{\mathrm{abA}}{60.89 \pm 3.23}$ \\
\hline $\begin{array}{l}\text { Experiment } \\
\text { group IV }\end{array}$ & $\underset{b F}{17.96 \pm 0.01}$ & $\underset{\mathrm{E}}{32.52 \pm 0.02^{\mathrm{b}}}$ & $\begin{array}{c}40.00 \pm 0.06^{\mathrm{ab}} \\
\mathrm{D}\end{array}$ & $\underset{\mathrm{C}}{45.78 \pm 0.01^{\mathrm{ac}}}$ & $54.00 \pm 0.04^{\mathrm{abB}}$ & $61.04 \pm 0.04^{\mathrm{aA}}$ \\
\hline $\begin{array}{l}\text { Experiment } \\
\text { group } \mathrm{V}\end{array}$ & $\underset{\mathrm{bD}}{17.63 \pm 0.03}$ & $\underset{\mathrm{aC}}{39.17 \pm 0.02}$ & $42.46 \underset{C}{ \pm 0.05^{\mathrm{a}}}$ & $50.86 \pm 0.04^{\mathrm{aB}}$ & $58.43 \pm 0.07^{\mathrm{aA}}$ & $61.22 \pm 0.01^{\mathrm{aA}}$ \\
\hline $\begin{array}{l}\text { Control } \\
\text { group II }\end{array}$ & $\underset{b F}{16.78 \pm 2.50}$ & $\underset{d E}{28.24 \pm 5.83^{c}}$ & $\underset{\mathrm{D}}{35.51 \pm 4.15^{\mathrm{bc}}}$ & $43.13 \pm 7.48^{\mathrm{ad}}$ & $\underset{B}{49.66 \pm 3.95^{\text {bcde }}}$ & $\underset{\mathrm{dA}}{54.26 \pm 3.93^{\mathrm{bc}}}$ \\
\hline
\end{tabular}

Values with different small letter superscripts in the same column or values with different capital letter superscripts in the same row mean significant difference $(P<0.05)$, and without or with same letter superscripts mean no difference $(P>0.05)$. The same as below.

The Rapidly degradable fraction (a) in the control group I was up to $15.01 \%(P<0.05)$, the lowest in group III was $6.42 \%(P<0.05)$. Slowly degradable fraction (b) and potentially degradable fraction $(a+b)$ in the experiment group were higher than those in control group. The highest effective degradation was in the group II $(P<0.05)$, followed by the group $\mathrm{V}$, the group IV, the group III, the control group II, the group I, the control group I (Table 4). 
Table 4 Model parameters of DM dynamic degradation for different forage

\begin{tabular}{lccccc}
\hline Species & $\begin{array}{l}\text { Rapidly } \\
\text { degradable } \\
\text { fraction } \\
(\mathrm{a}, \%)\end{array}$ & $\begin{array}{l}\text { Slowly } \\
\text { degradable } \\
\text { fraction } \\
(\mathrm{b}, \%)\end{array}$ & $\begin{array}{l}\text { Degradation } \\
\text { rate of } \mathrm{b} \\
(\mathrm{c}, \% / \mathrm{h})\end{array}$ & $\begin{array}{l}\text { Potentially } \\
\text { degradable } \\
\text { fraction }(\mathrm{a}+\mathrm{b}, \%)\end{array}$ & $\begin{array}{l}\text { Effective } \\
\text { degradation } \\
(\mathrm{ED}, \%)\end{array}$ \\
\hline $\begin{array}{l}\text { Control } \\
\text { group I }\end{array}$ & $15.01 \pm 0.48 \mathrm{a}$ & $34.35 \pm 4.09 \mathrm{~g}$ & $\begin{array}{c}0.0401 \pm 0.0158 \\
\mathrm{f}\end{array}$ & $49.36 \pm 3.73 \mathrm{~g}$ & $37.93 \pm 2.01 \mathrm{~g}$ \\
$\begin{array}{l}\text { Experiment } \\
\text { group I }\end{array}$ & $7.5 \pm 3.06 \mathrm{~d}$ & $52.40 \pm 3.02 \mathrm{~d}$ & $\begin{array}{c}0.0379 \pm 0.0078 \\
\mathrm{~g}\end{array}$ & $59.88 \pm 5.12 \mathrm{e}$ & $41.0 \pm 3.97 \mathrm{f}$ \\
$\begin{array}{l}\text { Experiment } \\
\text { group II }\end{array}$ & $6.42 \pm 7.05 \mathrm{f}$ & $55.11 \pm 6.59 \mathrm{c}$ & $\begin{array}{c}0.1050 \pm 0.0237 \\
\mathrm{a}\end{array}$ & $61.55 \pm 8.44 \mathrm{~b}$ & $52.71 \pm 7.96 \mathrm{a}$ \\
$\begin{array}{l}\text { Experiment } \\
\text { group III }\end{array}$ & $4.03 \pm 1.77 \mathrm{~g}$ & $58.13 \pm 1.8537 \mathrm{a}$ & $\begin{array}{c}0.0444 \pm 0.0044 \\
\mathrm{e}\end{array}$ & $62.34 \pm 2.56 \mathrm{a}$ & $44.36 \pm 2.63 \mathrm{~d}$ \\
$\begin{array}{l}\text { Experiment } \\
\text { group IV }\end{array}$ & $10.59 \pm 2.93 \mathrm{~b}$ & $49.04 \pm 2.7993 \mathrm{e}$ & $0.0580 \pm 0.0087$ & $60.23 \pm 2.99 \mathrm{~d}$ & $47.06 \pm 5.11 \mathrm{c}$ \\
$\begin{array}{l}\text { Experiment } \\
\text { group V }\end{array}$ & $6.88 \pm 4.92 \mathrm{e}$ & $53.49 \pm 4.6224 \mathrm{~b}$ & $0.0753 \pm 0.0013$ & $60.45 \pm 5.26 \mathrm{c}$ & $49.14 \pm 5.19 \mathrm{~b}$ \\
$\begin{array}{l}\mathrm{d} \text { Control } \\
\text { group II }\end{array}$ & $8.57 \pm 0.97 \mathrm{c}$ & $45.06 \pm 2.61 \mathrm{f}$ & $0.0602 \pm 0.009 \mathrm{c}$ & $53.63 \pm 1.60 \mathrm{f}$ & $42.39 \pm 1.66 \mathrm{e}$ \\
\hline
\end{tabular}

Values with different small letter superscripts in the same column mean significant difference $(P<0.05)$, and with same letter superscripts mean no difference $(P>0.05)$. The same as below.

\section{Digest regularity of the white goats to forage $C P$}

The degradation rate of $\mathrm{CP}$ was gradually increasing with the time. There existed significant difference $(P<0.05)$ in six timings among the group IV and control group II. The degradation rates of the group II rarely changed at between $16 \mathrm{~h}$ and $72 \mathrm{~h}$, and were much higher but indistinctly different $(P>0.05)$ before $16 \mathrm{~h}$, which was good for fast absorption and utilization of forage. The degradation rate of the control group I (forage grasses) at any time was lower than that of other experiment groups and the control group II. The degradation rate had a quick increase with the increasing proportion of legume at 24, 48 and $72 \mathrm{~h}$ (Table 5).

Table 5 Dynamic degradation rate of the forage CP in Guizhou white goats' rumen

\begin{tabular}{|c|c|c|c|c|c|c|}
\hline \multirow{2}{*}{ Item } & \multicolumn{6}{|c|}{ Degradation time (h) } \\
\hline & 4 & 8 & 16 & 24 & 48 & 72 \\
\hline $\begin{array}{l}\text { Control } \\
\text { group I }\end{array}$ & $\underset{\mathrm{dD}}{21.29 \pm 1.85}$ & $\underset{C D}{26.14 \pm 4.56^{\mathrm{e}}}$ & $\underset{C}{31.66 \pm 8.18^{\mathrm{d}}}$ & $\underset{B}{41.29 \pm 10.34^{f}}$ & $\underset{A B}{45.18 \pm 8.12^{\mathrm{d}}}$ & $\underset{A}{54.13 \pm 4.31^{\mathrm{d}}}$ \\
\hline $\begin{array}{l}\text { Experiment } \\
\text { group I }\end{array}$ & $\begin{array}{c}28.53 \pm 0.85 \\
\mathrm{cE}\end{array}$ & $\underset{E}{30.73 \pm 1.49^{d}}$ & $\begin{array}{c}38.52 \pm 1.79^{c} \\
D\end{array}$ & $50.21 \pm 2.14^{\mathrm{eC}}$ & $\underset{B}{60.61 \pm 2.73^{b c}}$ & $\underset{\mathrm{cA}}{66.77 \pm 7.78^{\mathrm{b}}}$ \\
\hline $\begin{array}{l}\text { Experiment } \\
\text { Group II }\end{array}$ & $\underset{\mathrm{aC}}{36.58 \pm 3.46}$ & $\underset{\mathrm{B}}{53.44 \pm 1.70^{\mathrm{a}}}$ & $\underset{A}{61.64 \pm 8.18^{\mathrm{a}}}$ & $\underset{\mathrm{A}}{62.77 \pm 6.75^{\mathrm{ab}}}$ & $\underset{\mathrm{A}}{63.23 \pm 4.08^{\mathrm{ac}}}$ & $\underset{c A}{69.75 \pm 0.25^{\mathrm{a}}}$ \\
\hline $\begin{array}{l}\text { Experiment } \\
\text { group III }\end{array}$ & $33.43 \pm 1.2^{\mathrm{bE}}$ & $\begin{array}{c}45.70 \pm 2.62^{\mathrm{c}} \\
\mathrm{D}\end{array}$ & $\underset{\mathrm{C}}{57.84 \pm 1.41^{\mathrm{a}}}$ & $\underset{B}{62.45 \pm 3.70^{\mathrm{ad}}}$ & $\underset{\mathrm{B}}{64.66 \pm 1.83^{\mathrm{ab}}}$ & $\underset{b A}{70.04 \pm 1.35^{\mathrm{a}}}$ \\
\hline $\begin{array}{l}\text { Experiment } \\
\text { group IV }\end{array}$ & $\underset{b F}{33.52 \pm 0.95}$ & $\underset{\mathrm{E}}{47.40 \pm 1.81^{\mathrm{bc}}}$ & $\underset{b D}{55.24 \pm 4.56^{\mathrm{a}}}$ & $\underset{C}{62.67 \pm 0.56^{\mathrm{ac}}}$ & $\underset{B}{66.81 \pm 3.55^{\mathrm{a}}}$ & $\underset{\mathrm{A}}{71.95 \pm 1.23^{\mathrm{a}}}$ \\
\hline $\begin{array}{l}\text { Experiment } \\
\text { group V }\end{array}$ & $\underset{\mathrm{aE}}{36.19 \pm 2.46}$ & $\underset{\mathrm{D}}{51.88 \pm 1.47^{\mathrm{ab}}}$ & $\underset{\mathrm{C}}{57.76} \pm 3.47^{\mathrm{a}}$ & $68.78 \pm 2.49^{\mathrm{aB}}$ & $\underset{B}{67.50 \pm 2.72^{\mathrm{a}}}$ & $\underset{A}{72.87 \pm 2.06^{\mathrm{a}}}$ \\
\hline $\begin{array}{l}\text { Control } \\
\text { group II }\end{array}$ & $\begin{array}{c}33.32 \pm 2.00 \\
\mathrm{bF}\end{array}$ & $\underset{\mathrm{E}}{44.91 \pm 4.48^{\mathrm{c}}}$ & $\begin{array}{c}50.50 \pm 3.19^{b} \\
D\end{array}$ & $\underset{\mathrm{dC}}{58.35 \pm 5.48^{\mathrm{bc}}}$ & $\begin{array}{c}67.97 \pm 2.51^{\mathrm{a}} \\
\mathrm{B}\end{array}$ & $\underset{\mathrm{A}}{73.89 \pm 2.24^{\mathrm{a}}}$ \\
\hline
\end{tabular}

The CP rapid degradable fraction (a) of each group had a significant difference $(P<0.05)$, in which the highest figure occurred in the group IV with $22.29 \%$, followed by the group I and V with over $20 \%$. The slow degradable fraction (b) also had a significant difference $(P<0.05)$, in which the highest one was the group II, followed by the group I and III, the control group II, all over 50\%. Degradation rates of $b$ in test group II and III were relatively higher and were more than $0.1 \%$. There were significant differences in potentially degradable fraction $(P<0.05)$, and they were higher in experiment group I and II. The highest of effective degradation rate was in experiment group II, followed by the group IV, V and III, the control group II, the group I, the control group I (Table 6). 
Table 6 Model parameters of CP dynamic degradation for different forage

\begin{tabular}{llllll}
\hline Species & $\begin{array}{l}\text { Rapidly } \\
\text { degradable } \\
\text { fraction } \\
(\mathrm{a}, \%)\end{array}$ & $\begin{array}{l}\text { Slowly } \\
\text { degradable } \\
\text { fraction } \\
(\mathrm{b}, \%)\end{array}$ & $\begin{array}{l}\text { Degradation } \\
\text { rate of b } \\
(\mathrm{c}, \% / \mathrm{h})\end{array}$ & $\begin{array}{l}\text { Potentially } \\
\text { degradable } \\
\text { fraction }(\mathrm{a}+\mathrm{b}, \%)\end{array}$ & $\begin{array}{l}\text { Effective } \\
\text { degradation } \\
(\mathrm{ED}, \%)\end{array}$ \\
\hline $\begin{array}{l}\text { Control } \\
\text { group I }\end{array}$ & $9.89 \pm 0.33^{\mathrm{g}}$ & $40.07 \pm 3.51^{\mathrm{g}}$ & $0.0594 \pm 0.014^{\mathrm{e}}$ & $49.96 \pm 0.96^{\mathrm{g}}$ & $39.87 \pm 2.12^{\mathrm{f}}$ \\
$\begin{array}{l}\text { Experiment } \\
\text { group I }\end{array}$ & $21.31 \pm 2.30^{\mathrm{b}}$ & $52.29 \pm 3.26^{\mathrm{c}}$ & $\begin{array}{c}0.0287 \pm 0.0062 \\
\mathrm{~g}\end{array}$ & $73.54 \pm 3.11^{\mathrm{a}}$ & $52.13 \pm 3.24^{\mathrm{e}}$ \\
$\begin{array}{l}\text { Experiment } \\
\text { group II }\end{array}$ & $16.67 \pm 6.11^{\mathrm{d}}$ & $55.99 \pm 4.14^{\mathrm{a}}$ & $\begin{array}{c}0.1050 \pm 0.0237 \\
\mathrm{a}\end{array}$ & $72.46 \pm 10.22^{\mathrm{b}}$ & $63.70 \pm 10.24^{\mathrm{a}}$ \\
$\begin{array}{l}\text { Experiment } \\
\text { group III }\end{array}$ & $16.47 \pm 2.57^{\mathrm{e}}$ & $50.99 \pm 2.39^{\mathrm{d}}$ & $\begin{array}{c}0.1032 \pm 0.0091 \\
\mathrm{~b}\end{array}$ & $67.16 \pm 3.65^{\mathrm{f}}$ & $59.18 \pm 4.34 \mathrm{c}^{\mathrm{d}}$ \\
$\begin{array}{l}\text { Experiment } \\
\text { group IV }\end{array}$ & $22.29 \pm 2.64^{\mathrm{a}}$ & $47.84 \pm 2.47^{\mathrm{f}}$ & $\begin{array}{c}0.0787 \pm 0.0087 \\
\mathrm{c}\end{array}$ & $69.96 \pm 2.13^{\mathrm{e}}$ & $60.44 \pm 1.77^{\mathrm{b}}$ \\
$\begin{array}{l}\text { Experiment } \\
\text { group V }\end{array}$ & $20.72 \pm 4.38^{\mathrm{c}}$ & $49.64 \pm 4.13^{\mathrm{e}}$ & $\begin{array}{c}0.0753 \pm 0.0142 \\
\mathrm{~d}\end{array}$ & $70.34 \pm 4.86^{\mathrm{d}}$ & $59.9 \pm 5.09^{\mathrm{bc}}$ \\
$\begin{array}{l}\text { Control } \\
\text { group II }\end{array}$ & $16.19 \pm 0.89^{\mathrm{f}}$ & $54.73 \pm 2.33^{\mathrm{b}}$ & $0.0729 \pm 0.0074$ & $70.92 \pm 0.92^{\mathrm{c}}$ & $59.14 \pm 4.36^{\mathrm{d}}$ \\
\hline
\end{tabular}

\section{Digest regularity of white goats to forage NDF}

The neutral detergent fiber (NDP) degradation rate increased gradually with the extension of forage degradation time in goats' rumen in each experiment group. The degradation rates changed slowly in the group I and the differences were not significant during 4-24 h, $(P>0.05)$. The values of the group II in 16h were the highest and had great differences, compared with other groups at 4-16 h and $72 \mathrm{~h}(P<0.05)$. The value of the group II at $16 \mathrm{~h}$ was the highest and the differences were significant $(P<0.05)$ compared with other experiment groups. The degradation rate at $72 \mathrm{~h}$ did not appear a distinct changing tendency with the decreasing of forage grass. The degradation rate of the group II at $72 \mathrm{~h}$ was the highest, followed by those of the control group I, the group I, the group V, the control group II, the group IV and the group III (Table 7).

Table 7 Dynamic degradation rate of the forage NDF in Guizhou white goats' rumen

\begin{tabular}{|c|c|c|c|c|c|c|}
\hline \multirow{2}{*}{ Item } & \multicolumn{6}{|c|}{ Degradation time $(\mathrm{h})$} \\
\hline & 4 & 8 & 16 & 24 & 48 & 72 \\
\hline $\begin{array}{l}\text { Control } \\
\text { group I }\end{array}$ & $\underset{\mathrm{D}}{12.94 \pm 3.20^{\mathrm{b}}}$ & $15.77 \pm 4.50^{\mathrm{bD}}$ & $\underset{C D}{21.08 \pm 11.53^{b}}$ & $\underset{B C}{28.56 \pm 15.41^{\mathrm{ab}}}$ & $\begin{array}{c}39.15 \pm 18.98^{\mathrm{abd}} \\
\mathrm{AB}\end{array}$ & $45.47 \pm 7.02^{\mathrm{bA}}$ \\
\hline $\begin{array}{l}\text { Experiment } \\
\text { group I }\end{array}$ & $9.60 \pm 0.91^{\mathrm{dB}}$ & $11.8 \pm 2.96^{\mathrm{cdeB}}$ & $16.2 \pm 2.02^{\mathrm{bB}}$ & $18.73 \pm 3.50^{\mathrm{bB}}$ & $33.86 \pm 4.59 \mathrm{acA}$ & $\underset{\mathrm{bA}}{41.02 \pm 13.82}$ \\
\hline $\begin{array}{l}\text { Experiment } \\
\text { group II }\end{array}$ & $\underset{\mathrm{C}}{15.42 \pm 1.23^{\mathrm{a}}}$ & $20.01 \pm 2.60^{\mathrm{aC}}$ & $\underset{B C}{30.11 \pm 14.90^{a}}$ & $36.91 \pm 16.86^{\mathrm{aB}}$ & $45.12 \pm 1.62^{\mathrm{aAB}}$ & $58.44 \pm 0.35^{\mathrm{aA}}$ \\
\hline $\begin{array}{l}\text { Experiment } \\
\text { group III }\end{array}$ & $11.60 \pm \underset{d E}{ \pm} 1.71^{b}$ & $\begin{array}{c}13.45 \pm 2.50^{\mathrm{bd}} \\
\mathrm{D}\end{array}$ & $16.82 \pm 1.54^{\mathrm{bC}}$ & $18.82 \pm 3.38^{\mathrm{bC}}$ & $25.70 \pm 2.13^{\mathrm{cB}}$ & $\underset{\mathrm{eA}}{30.84 \pm 3.87^{\mathrm{cd}}}$ \\
\hline $\begin{array}{l}\text { Experiment } \\
\text { group IV }\end{array}$ & $\underset{c D}{12.46 \pm 1.63^{b}}$ & $\begin{array}{c}15.04 \pm 1.78^{\mathrm{bc}} \\
\mathrm{D}\end{array}$ & $18.75 \pm 1.99^{\mathrm{bC}}$ & $21.06 \pm 0.85^{\mathrm{bC}}$ & $27.76 \pm 7.72^{\mathrm{bcB}}$ & $\underset{A}{37.11 \pm 2.37^{\text {be }}}$ \\
\hline $\begin{array}{l}\text { Experiment } \\
\text { group } \mathrm{V}\end{array}$ & $\underset{\mathrm{dD}}{10.35 \pm 1.04^{\mathrm{c}}}$ & $\underset{C D}{13.46 \pm 0.60^{\mathrm{bd}}}$ & $15.28 \pm 1.15^{\mathrm{bC}}$ & $17.05 \pm 6.62^{\mathrm{bC}}$ & $26.77 \pm 1.81^{\mathrm{cB}}$ & $\underset{\mathrm{A}}{38.28 \pm 2.41^{\mathrm{bc}}}$ \\
\hline $\begin{array}{l}\text { Control } \\
\text { group II }\end{array}$ & $6.73 \pm 1.86^{\mathrm{eE}}$ & ${ }_{D}^{12.70 \pm 3.62^{\text {be }}}$ & $16.91 \pm 3.24^{\mathrm{bD}}$ & $22.30 \pm 4.17^{\mathrm{bC}}$ & $27.50 \pm 3.81^{\mathrm{cdB}}$ & $\underset{A}{37.96 \pm 3.85^{\text {bd }}}$ \\
\hline
\end{tabular}

The rapidly degradable fraction of NDF of the group II, III and IV were relatively higher and were more than $10 \%$. The lowest one of $5.28 \%$ was in the control group II. Slowly degradable fraction of the group II was up to $53.88 \%$, which was significantly different from those in other groups $(P<0.05)$. The highest degradation rates of $b$ were in the control group I and the group II. The rate differences were not significant in these two groups $(P>0.05)$, but significant in between these two groups and other groups $(P<0.05)$. The highest of potentially degradable fraction was in the group II, the slowest one was in the group IV. The highest of effective degradation was in the group II, followed by the control group I and II, the group IV, V, III and I (Table 8). 
Table 8 Model parameters of NDF dynamic degradation for different forage

\begin{tabular}{|c|c|c|c|c|c|}
\hline Species & $\begin{array}{l}\text { Rapidly } \\
\text { degradable } \\
\text { fraction } \\
(a, \%)\end{array}$ & $\begin{array}{l}\text { Slowly } \\
\text { degradable } \\
\text { fraction } \\
(\mathrm{b}, \%)\end{array}$ & $\begin{array}{l}\text { Degradation } \\
\text { rate of b } \\
(\mathrm{c}, \% / \mathrm{h})\end{array}$ & $\begin{array}{l}\text { Potentially } \\
\text { degradable } \\
\text { fraction }(a+b \text {, } \\
\%)\end{array}$ & $\begin{array}{l}\text { Effective } \\
\text { degradation } \\
(\mathrm{ED}, \%)\end{array}$ \\
\hline $\begin{array}{l}\text { Control group } \\
\text { I }\end{array}$ & $7.4 \pm 1.59^{f}$ & $45.44 \pm 11.37^{b}$ & $\begin{array}{l}0.0251 \pm 0.015 \\
1^{\mathrm{a}}\end{array}$ & $52.84 \pm 12.34^{b}$ & $32.69 \pm 8.65^{b}$ \\
\hline $\begin{array}{l}\text { Experiment } \\
\text { group I }\end{array}$ & $6.83 \pm 3.19^{\mathrm{e}}$ & $40.54 \pm 2.45^{\mathrm{e}}$ & $\begin{array}{l}0.0125 \pm 0.007 \\
2^{\text {cd }}\end{array}$ & $47.62 \pm 3.11^{\mathrm{e}}$ & $22.42 \pm 2.64^{\mathrm{f}}$ \\
\hline $\begin{array}{l}\text { Experiment } \\
\text { group II }\end{array}$ & $10.48 \pm 5.19^{b}$ & $53.88 \pm 12.56^{\mathrm{a}}$ & $\begin{array}{l}0.0260 \pm 0.015 \\
8^{\mathrm{a}}\end{array}$ & $64.24 \pm 10.36^{\mathrm{d}}$ & $\begin{array}{l}40.93 \pm 13.00 \\
\mathrm{a}\end{array}$ \\
\hline $\begin{array}{l}\text { Experiment } \\
\text { group III }\end{array}$ & $10.05 \pm 1.11^{\mathrm{c}}$ & $34.01 \pm 11.72^{f}$ & $\begin{array}{l}0.0130 \pm 0.007 \\
2^{\text {bd }}\end{array}$ & $43.25 \pm 9.96^{\mathrm{g}}$ & $23.45 \pm 12.89$ \\
\hline $\begin{array}{l}\text { Experiment } \\
\text { group IV }\end{array}$ & $11.71 \pm 1.24^{\mathrm{a}}$ & $33.11 \pm 3.76^{\mathrm{g}}$ & $\begin{array}{l}0.0141 \pm 4.901 \\
2^{\mathrm{bc}}\end{array}$ & $44.82 \pm 4.18^{\mathrm{f}}$ & $25.40 \pm 6.11^{\mathrm{c}}$ \\
\hline $\begin{array}{l}\text { Experiment } \\
\text { group } \mathrm{V}\end{array}$ & $9.33 \pm 1.24^{\mathrm{d}}$ & $41.43 \pm 1.90^{\mathrm{d}}$ & $\begin{array}{l}0.0123 \pm 2.330 \\
0^{\text {cd }}\end{array}$ & $50.76 \pm 3.10^{c}$ & $25.11 \pm 5.90^{\mathrm{d}}$ \\
\hline $\begin{array}{l}\text { Control } \\
\text { groupII }\end{array}$ & $5.28 \pm 0.72^{\mathrm{g}}$ & $44.25 \pm 8.64^{\mathrm{c}}$ & $\begin{array}{l}0.0171 \pm 0.006 \\
5^{\mathrm{b}}\end{array}$ & $49.53 \pm 9.66^{\mathrm{d}}$ & $25.68 \pm 4.62^{\mathrm{c}}$ \\
\hline
\end{tabular}

\section{Digest regularity of white goats to forage ADF}

The degradation rate of acid detergent fiber (ADF) was increasing with the degradation time of each group. The digestive regularity was the highest in these six points of time in the group II, and the degradation rate at $48 \mathrm{~h}$ of this group was significantly different from those of other groups $(P<0.05)$. Compared with the degradation rates at $4 \mathrm{~h}, 8 \mathrm{~h}, 16 \mathrm{~h}, 24 \mathrm{~h}$ and $72 \mathrm{~h}$ in between the groups and the control groups, only the degradation rate in the group II was higher than those in the control groups. The degradation rates were all lower in other experiment groups than in the control groups. The order of the degradation rates at $72 \mathrm{~h}$ in all the groups were the group II $>$ the control group I $>$ the control group II $>$ the group I $>$ the group V $>$ the group IV $>$ the group III (Table 9).

Table 9 Dynamic degradation rate of the forage ADF in Guizhou white goats' rumen

\begin{tabular}{|c|c|c|c|c|c|c|}
\hline \multirow{2}{*}{ Item } & \multicolumn{6}{|c|}{ Degradation time $(\mathrm{h})$} \\
\hline & 4 & 8 & 16 & 24 & 48 & 72 \\
\hline $\begin{array}{l}\text { Control } \\
\text { group I }\end{array}$ & $\underset{\mathrm{eE}}{7.74 \pm 1.28^{\mathrm{cd}}}$ & $\underset{\mathrm{DE}}{13.16 \pm 3.48^{\mathrm{cC}}}$ & $25.45 \pm 8.30^{\mathrm{aBD}}$ & $\underset{B C}{26.66 \pm 15.82^{b}}$ & $\underset{A B}{34.29 \pm 17.31^{b}}$ & $\underset{b A}{46.40 \pm 17.38^{\mathrm{a}}}$ \\
\hline $\begin{array}{l}\text { Experiment } \\
\text { group I }\end{array}$ & $\underset{\mathrm{eB}}{7.62 \pm 1.10^{\mathrm{cd}}}$ & $10.8 \pm 0.88^{\mathrm{ceB}}$ & $11.6 \pm 0.80^{\mathrm{bB}}$ & $14.56 \pm 3.68 \mathrm{~b}^{\mathrm{B}}$ & $33.58 \pm 4.61^{\mathrm{bA}}$ & $\underset{\mathrm{dA}}{41.00 \pm 13.82^{\mathrm{b}}}$ \\
\hline $\begin{array}{l}\text { Experiment } \\
\text { group II }\end{array}$ & $\underset{\mathrm{E}}{17.60 \pm 1.91^{\mathrm{a}}}$ & $\underset{\mathrm{E}}{26.10 \pm 1.14^{\mathrm{aD}}}$ & $\underset{C D}{32.24 \pm 14.45^{\mathrm{aB}}}$ & $\underset{A C}{39.76 \pm 16.10^{a}}$ & $\underset{\mathrm{B}}{45.89 \pm 1.68^{\mathrm{aA}}}$ & $52.25 \pm 0.40^{\mathrm{aA}}$ \\
\hline $\begin{array}{l}\text { Experiment } \\
\text { group III }\end{array}$ & $9.45 \pm 1.26^{\mathrm{bE}}$ & $\begin{array}{c}11.82 \pm 1.07^{\mathrm{cd}} \\
\mathrm{DE}\end{array}$ & $14.14 \pm 2.88^{b D}$ & $21.85 \pm 3.25^{\mathrm{bC}}$ & $28.96 \pm 2.02^{\mathrm{bB}}$ & $\underset{A}{34.25 \pm 3.68^{\mathrm{cd}}}$ \\
\hline $\begin{array}{l}\text { Experiment } \\
\text { group IV }\end{array}$ & $\begin{array}{c}8.46 \pm 0.98^{\text {be }} \\
\text { D }\end{array}$ & $10.78 \pm 1.59^{\mathrm{cfD}}$ & $14.23 \pm 1.55^{\mathrm{bC}}$ & $17.33 \pm 1.25^{\mathrm{bC}}$ & $30.66 \pm 7.41^{\mathrm{bB}}$ & $\underset{A}{35.79 \pm 2.42^{\mathrm{cd}}}$ \\
\hline $\begin{array}{l}\text { Experiment } \\
\text { group V }\end{array}$ & $\underset{B}{8.90 \pm 0.82^{\text {bd }}}$ & $9.02 \pm 2.78^{\operatorname{defB}}$ & $15.47 \pm 0.77^{\mathrm{bA}}$ & $19.61 \pm 6.41^{\mathrm{bA}}$ & $31.02 \pm 1.02^{\mathrm{bA}}$ & $\underset{\mathrm{A}}{40.99 \pm 2.31^{\mathrm{acd}}}$ \\
\hline $\begin{array}{l}\text { Control } \\
\text { group II }\end{array}$ & $\begin{array}{c}9.01 \pm 1.82^{\mathrm{bc}} \\
\mathrm{D}\end{array}$ & $22.93 \pm 3.19^{\mathrm{bC}}$ & $25.78 \pm 2.90^{\mathrm{aC}}$ & $\underset{C}{26.99 \pm 3.92^{\mathrm{abB}}}$ & $30.58 \pm 3.64^{\mathrm{bB}}$ & $\underset{A}{41.03 \pm 3.66^{b c}}$ \\
\hline
\end{tabular}

The rapidly degradable fraction of ADF was the highest in the group II, and was the lowest in the group I. Rapidly degradable fraction of ADF in control group I was significantly different from those in other groups $(P<0.05)$. Slowly degradable fraction was the highest in control group I, and was the lowest in control group II $(P<0.05)$. Degradation rates of $b$ of the control II and the group II were the highest. Potentially degradable fraction was the highest in the control group I, and was the lowest in the control group II. Effective degradation was the highest in the group II, followed by those in the control group I and II, the group V, III, I and IV (Table 10). 
Table 10 Model parameters of ADF dynamic degradation for different forage

\begin{tabular}{clllll}
\hline Species & $\begin{array}{l}\text { Rapidly } \\
\text { degradable } \\
\text { fraction } \\
(\mathrm{a}, \%)\end{array}$ & $\begin{array}{l}\text { Slowly } \\
\text { degradable } \\
\text { fraction } \\
(\mathrm{b}, \%)\end{array}$ & $\begin{array}{l}\text { Degradation } \\
\text { rate of b } \\
(\mathrm{c}, \% / \mathrm{h})\end{array}$ & $\begin{array}{l}\text { Potentially } \\
\text { degradable } \\
\text { fraction(a+b,\%) }\end{array}$ & $\begin{array}{l}\text { Effective } \\
\text { degradation } \\
(\mathrm{ED}, \%)\end{array}$ \\
\hline $\begin{array}{c}\text { Control } \\
\text { group I }\end{array}$ & $4.54 \pm 1.42^{\mathrm{e}}$ & $47.91 \pm 12.12^{\mathrm{a}}$ & $0.0247 \pm 0.0014$ & $52.45 \pm 12.45^{\mathrm{a}}$ & $31.01 \pm 9.32^{\mathrm{b}}$ \\
$\begin{array}{c}\text { Experiment } \\
\text { group I } \\
\text { Experiment } \\
\text { group II }\end{array}$ & $6.50 \pm 2.98^{\mathrm{b}}$ & $41.45 \pm 11.92^{\mathrm{d}}$ & $0.0123 \pm 0.0043^{\mathrm{e}}$ & $47.95 \pm 12.45^{\mathrm{e}}$ & $22.28 \pm 8.12^{\mathrm{e}}$ \\
$\begin{array}{c}\text { Experiment } \\
\text { group III }\end{array}$ & $6.37 \pm 1.30^{\mathrm{b}}$ & $34.49 \pm 7.23^{\mathrm{f}}$ & $0.0173 \pm 0.0064^{\mathrm{d}}$ & $40.58 \pm 8.24^{\mathrm{f}}$ & $22.37 \pm 5.10^{\mathrm{e}}$ \\
$\begin{array}{c}\text { Experiment } \\
\text { group IV } \\
\text { Experiment } \\
\text { group V }\end{array}$ & $5.83 \pm 1.27^{\mathrm{cd}}$ & $43.21 \pm 3.10^{\mathrm{b}}$ & $0.0101 \pm 0.0058^{\mathrm{f}}$ & $49.45 \pm 5.43^{\mathrm{c}}$ & $20.33 \pm 10.23^{\mathrm{f}}$ \\
$\begin{array}{c}\text { Control } \\
\text { group II }\end{array}$ & $6.16 \pm 1.45^{\mathrm{d}}$ & $42.29 \pm 4.89^{\mathrm{c}}$ & $0.0169 \pm 0.0051^{\mathrm{d}}$ & $48.33 \pm 4.16^{\mathrm{d}}$ & $25.11 \pm 5.56^{\mathrm{d}}$ \\
\hline
\end{tabular}

\section{Discussion}

\section{Digest regularity of mixed forage DM and development of grassland stockbreeding}

Dry matter is an important indicator to measure the accumulation of plant organic matter and the number of nutritional matter. The degradation rate of DM in rumen is considered as a major factor in influencing DM intake ${ }^{[21]}$, and it is also regarded as an important indicator in improving synergy emission reduction and evaluating forage grass quality. This experiment results indicate that the degradation rate of DM would increase gradually with the increasing incubation time of forage in rumen, because the digesting process of nutrient substance was complex and was influenced by both rumen microbes and enzyme. For the hardly degradable substance, much more sufficient fermentation time was needed. The longer the degradation time, the longer the rumen microbial action time, and the degradation of nutritional substance in forage will be more sufficient, which is consistent with previous findings of $\mathrm{Qi}{ }^{[22]}$ and $\mathrm{Mehrez}^{[23]}$. This experiment found that the degradation rate in the grasses and legume mixed forage at $72 \mathrm{~h}$ was bigger than that in single forage, the effective degradation was bigger than control group except the experiment group I. It indicates that the mixed match of the grasses and the legume could contribute to improving the nutrition percent conversion of forage and could also improve the quality. For the future governing of rocky desertification, developing grass stockbreeding should strengthen the planting techniques in mixed match of the grass family and legume, which could not only improve the quality of soil but also was suitable to the development of grassland stockbreeding in rocky desertification areas.

\section{Digest regularity of mixed forage $\mathrm{CP}$ and development of grassland stockbreeding}

The degradation rate of $\mathrm{CP}$ is an indicator to reflect the nutrition absorption and utilization situations of forage ${ }^{[24]}$. It was inferred that, with the increasing proportion of legume alfalfa, the degradation rate of CP shows an increasing trend in $24-72 \mathrm{~h}$. The reason is that legume plants are of high protein and low fiber. Fiber is a sort of hard degradable substance; the higher forage protein level was accordant with the higher degradation rate of $\mathrm{CP}$, and the higher forage fiber accordant with the lower degradation rate, which was similar to the results of Huang ${ }^{[25]}$. The control group II is of the biggest degradation rate in legume CP. But legume could not be eaten much for a long time, because the forage could produce a lot of gas in the rumen causing a death of livestock for the expansion of rumen. The degradation rate of the experiment group II at 16-72h did not change a lot and the differences were not so distinct $(P>0.05)$. The degradation rate was bigger before $16 \mathrm{~h}$, which contributed to the quick protein absorption and utilization of Guizhou goats to forage, at the same time, the effective degradation rate of the Experiment group II was the biggest. It is comprehensively thought that the best mixed proportion is 3:7, which could stimulate bigger rate of 
absorption and utilization of protein within a short time. The grassland stockbreeding in the rocky desertification should consider much more on the speed of forage nutrition absorption and utilization, so some legume such as alfalfa, white clover high quality legume should be added in the livestock's fodder in order to acquire better economic benefit, which is just the same as the finding of Liu ${ }^{[26]}$ and other researchers.

\section{Digest regularity of mixed forage NDF, ADF and development of grassland stockbreeding}

The rumen elimination rate of NDF and ADF is an indicator of degree for coarse fodder digestion. The experiment results indicate that the best proportion should be 3:7 under the mixed situation of legume and grasses of NDF and ADF and the degradation rate was the biggest in six points of time, which might be excessive exercise of the white goat in the karst mountain area and the goat needs much crude fiber. It indicates that the replacement number of legume alfalfa is lower or higher and the degradation rate of dietary fiber decreased or even smaller than the control group, which might be the influence on the absorption ability of rumen to nutrition ingredient. The over-content of fiber could lead to the bearing of rumen degradation and lead to the slow degradation. The lack of significant differences in feed intake, nutrient digestibility and nitrogen utilization following the inclusion of the TMR ${ }^{[27]}$. The dynamic degradation of NDF and ADF in forage would increase gradually with time's lengthening staying in rumen; however, the degradation rate became slowly relatively within the former $8 \mathrm{~h}$, which because that NDF and ADF are the main ingredients in plant cell wall and rumen microbe firstly attaches to the bottom just to digest, which are the reasons making the degradation speed slow. This result was the same as the founding of $\mathrm{Yu}^{[28]}$. Wang ${ }^{[29]}$ proposed that more mixed feed were fed to livestock, ADF digestibility will be higher than control group and it has some differences in these experiment. It may be due to different composition of dietary.

\section{Conclusion}

Based on the former researches, it can be seen that both the matching technology of mixed forage and the development of grassland stockbreeding in rocky desertification are helpful each other. The collocation technology of mixed forage is to integrate the existing high quality forages, and to do scientific feeding, which not only to improve the eco-environment but also promote the development of local stockbreeding. The study draws that the nutrition conversion of the mixed forage is higher than that of the single forage; the best mixture percentage between legume and grasses is 3:7. As a result, we suggest this configuration proportion in the grass land construction and the grassland stockbreeding development of the national rocky desertification control.

Ecological intensification in grasslands can be regarded as a process for increasing forage production while maintaining high levels of ecosystem functions and biodiversity ${ }^{[30]}$. Obviously the matching technology of mixed forage is the main development direction of developing grassland stockbreeding in rocky desertification areas. How to increase the proportion of multispecies forage matching seeding is waiting for us to solve.

\section{Acknowledgements}

This work was financially supported by the Key Project of Guizhou Provincial Science and Technology Program(KPGZSTP20146007). Corresponding author: Kangning Xiong, Xiongkn@163.com

\section{References}

[1] Kangning Xiong, Lini Bai and Xianwei Peng: Carsologica Sinica Vol.2(2005), p. 41-47(In Chinese)

[2] Kangning Xiong: China Population Resources and Environment Vol.9(1999), p. 64-67(In Chinese)

[3] Daoxian Yuan :The problems and countermeasures in the treatment of rocky desertification. In: 
Study on Major Environment Geological Problems and Countermeasures in Karst Areas of Southwestern China( Science and Technology Press. China 2014). (In Chinese)

[4] Jianfei Gao, Xiaoliang Su, Kangning Xiong and Wei Zhou: Pratacultural Science Vol.27(2010), p.30-34(In Chinese)

[5] Yuansu Wang: Technology of grassland animal husbandry in Guizhou (Guizhou science and Technology Publishing House. China 2015). (In Chinese)

[6] Xiaoyun Shen: Application technology of grassland ecological animal husbandry in Karst mountainous area of Guizhou Province (Gansu science and Technology Publishing House. China 2015). (In Chinese)

[7]Hong Cao, Huiling Zhang, Qionghui Gai, Hong Chen and Manlai Zhao: Acta Prataculturae Sinica Vol.20(2011), p.219-229(In Chinese)

[8]Aike Bao, Qianglong Wang, Jinlin Zhang and Suomin Wang : Molecular Plant Breeding Vol.5(2007), p.160-168(In Chinese)

[9]Feng He, Dongmei Han, Liqiang Wan and Xianglin Li: Journal of Plant Nutrition and Fertilizer Vol.20(2014), p.503-509(In Chinese)

[10] Bentian Mo, Tianqiong Luo, Chengbin Tang and Yongfen Han: Grassland of China Vol.3(2000), p.29-33(In Chinese)

[11] Mingkun Zhao, Yishun Shang, Xigui Zhao and Jing He: Chinese Journal of Grassland Vol.28(2006),p.44-51(In Chinese)

[12] Qizhong Sun, Zhu Yu and Chuncheng: Pratacultural Science Vol. 29(2012) ,p. 314-319(In Chinese)

[13] Lun Shan and Bingcheng Xu :Acta Prataculturae Sinica Vol. 18(2009), p. 1-2(In Chinese)

[14]Yanyan Zhang, Laiye Qu, Liding Chen and Wei Wei : Chinese Journal of Applied Ecology Vol. 21(2010), p. 165-173(In Chinese)

[15] Kaiyun Xie, Yun Zhao, Xianglin Li, Feng He, Liqiang Wang, Dan Wang and Dongmei Han:Acta Prataculturae Sinica Vol. 22(2013), p. 284-296(In Chinese)

[16] LJ Xu, GX Yang, XP Xin, EQ Wu, GL Qing, SS Zhu and M Dong :Pratacultural Science Vol. 31(2014), p. 278-283

[17] Dexun Lu and Zongwen Xie: Method and technology for the modern ruminants nutrition (Agriculture Press. China. 1991) (In Chinese)

[18]TJ Hackmann, JD Sampson and JN Spain :Journal of Animal Science 2008

[19] ER Фrskov and L McDonald: Journal of Agriculture Science Cambridge Vol. 92(2014), p. 799-803

[20] L Donald: Agric Sci Vol. 96(1981), p. 251-252

[21] Ke Xia, Qing Yao, Fuguo Li, Min Li, Chunyu Duan, Weibin Xi and Yonggen Zhang: Chinese Journal of Animal Nutrition Vol. 24(2012), p. 769-777(In Chinese)

[22] Zhili Qi, Erdi Ga, Huijun Chen and Furong Zhao: Chinese Journal of Animal Nutrition Vol. 19(2007), p. 253-257(In Chinese)

[23] AZ Mehrez and ER Orskov: Journal of Agricultural Science Vol. 88(1977), p. 645-650

[24] Hongliang Liu and Yujie Lou: Chinese Journal of Grassland Vol. 28(2006), p.47-51(In Chinese)

[25] Xiusheng Huang, Xin Yang, Qinlou Huang, Zhongtian Chen, Deqing Feng and Zhenmei Zhong: Acta Prataculturae Sinica Vol. 19(2011), p. 62-68(In Chinese)

[26] M Blouin, Y Zuily-Fodil and PT Anh-Thu :Ecology Letter Vol. 8(2005), p.202-208

[27] DEM Thamsanqa and H Abubeker : Trop Anim Health Prod Vol. 47(2015), p.1391-1396

[28] Miao Yu, Rongzhen Zhong, Daowei Zhou and Fengxian Gao: Acta Prataculturae Sinica Vol. 22(2014), p.175-180(In Chinese)

[29] Li Wang, Yingjie Zhang, Yueqin Liu, Xuemei Li, Jiadong Yang, Lanhui Li and Hongxin Sun: The Symposium on Sheep Production Vol.12(2014), p.253-255(In Chinese)

[30] L Gregory, D Laurent, G Pierre: Environmental Management Vol. 56(2015), p. 1039-1052 